Gorana Mrđan*, Borko Matijević, Sanja Vlaisavljević, Đenđi Vaštag, Suzana Apostolov

University of Novi Sad, Faculty of Sciences, Department of Chemistry, Biochemistry and Environmental Protection, Novi Sad, Serbia
Scientific paper

ISSN 0351-9465, E-ISSN 2466-2585

UDC: 547.288.3: $665.7 .038 .5: 544.165$ doi: $10.5937 /$ zasmat2101005M

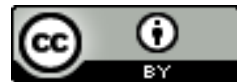

Zastita Materijala $62(1)$ 5 - 8 (2021)

\title{
Study of antioxidant activity of selected monocarbohydrazone derivatives
}

\begin{abstract}
Many of carbohydrazone derivatives have shown a wide range of biological activities. In previous studies, these compounds have proven to be excellent anti-cancer, antitumor, antibacterial, antimicrobial and antioxidant agents. Monocarbohydrazones, as one of the carbohydrazone derivatives, have been slightly explored. Due to that reason, in this study, eight newly synthesized monocarbohydrazones were subjected to examinations by the use of three antioxidant tests. To determine the effectiveness of monocarbohydrazone as potential radical scavengers, DPPH (2,2Diphenyl-1-picrylhydrazyl), ABTS (2,2'-azino-bis(3-ethylbenzothiazoline-6-sulfonic acid)) and FRAP (Ferric Reducing Antioxidant Power) assays were used. The obtained results could open the door for further studies of these compounds as biologically active substances.
\end{abstract}

Keywords: antioxidant, ABTS, biological activity, DPPH, FRAP, monocarbohydrazones

\section{INTRODUCTION}

Carbohydrazones are compounds obtained by condensation of carbohydrazide with carbonyl compounds, aldehydes and/or ketones. So far, a large number of these derivatives have been tested and they have proved to be excellent anti-cancer[1] antitumor [2], antimicrobial[3-5] and antioxidant[6] agents. Monocarbohydrazones, tested in this study, were obtained under strictly controlled reaction conditions. Inspired by previous results and the fact that monocarbohydrazones, as one of the carbohydrazone derivatives, have been poorly studied so far, several derivatives have been picked out in order to investigate their antioxidant activity using three different assays [7-9] DPPH, ABTS and FRAP.

DPPH (2,2-diphenyl-1-picrylhydrazyl) assay is the most common and accepted model for evaluating the free radical scavenging capacity. When antioxidants react with DPPH (purple colored), which is a stable free radical, it becomes

\footnotetext{
${ }^{*}$ Corresponding author: Gorana Mrđan

E-mail: gorana.mrdjan@dh.uns.ac.rs

Paper received: 25. 05. 2020.

Paper corrected: 20. 06. 2020.

Paper accepted: 20. 07. 2020.

Paper is available on the website: www.idk.org.rs/journal
}

paired off in the presence of a hydrogen donor and it is reduced to the DPPHH form (yellow colored) with respect to the number of electrons captured. More the decolorization stronger is the reducing ability of compound tested. ABTS (2,2'-azino-bis (3-ethylbenzothiazoline-6-sulfonic acid) assay is based on production of the blue/green ABTS ${ }^{\circ+}$ chromophore through the reaction between ABTS and potassium persulfate. Addition of antioxidants to the pre-formed radical cation reduces it back to its colorless neutral form, ABTS.

FRAP (Ferric Reducing Antioxidant Power) assay relies on the reduction of the complex ferric ion - TPTZ (2,4,6-tri(2-pyridyl)- 1,3,5-triazine). The binding of $\mathrm{Fe}^{2+}$ to the ligand creates a very intense navy-blue color. The absorbance is measured to test the amount of iron reduced and it can be correlated with the amount of antioxidants.

Trolox or ascorbic acid can be used as reference antioxidant. These assays were performed using a spectrophotometric method.

\section{EXPERIMENTAL PART}

Eight monocarbohydrazone derivatives were synthesized and characterized in the Department of Chemistry, Biochemistry and Environmental Protection (Faculty of Sciences, University of Novi Sad). The structure of these analysed compounds is shown in Table 1. 
Table 1. Structure of analysed monocarbohydrazones

Tabela 1. Struktura i oznaka ispitivanih monokarbohidrazona

\begin{tabular}{|c|c|c|}
\hline Structure & No & $\begin{array}{c}\text { Substituent } \\
(\mathrm{R})\end{array}$ \\
\hline \multirow[t]{8}{*}{$\mathrm{H}_{2} \mathrm{~N}-\mathrm{NH}$} & 1 & $\mathrm{H}$ \\
\hline & 2 & $4-\mathrm{OH}$ \\
\hline & 3 & $4-\mathrm{CH}_{3}$ \\
\hline & 4 & $4-\mathrm{NO}_{2}$ \\
\hline & 5 & $4-\mathrm{OCH}_{3}$ \\
\hline & 6 & $4-\mathrm{Cl}$ \\
\hline & 7 & 4-Br \\
\hline & 8 & $4-F$ \\
\hline
\end{tabular}

Solutions of all analysed derivatives were made in absolute dimethyl-sulfoxide (Sigma Aldrich), at a concentration of $5 \mathrm{mg} / \mathrm{mL}$.

\section{DPPH assay}

Prepared solutions of monocarbohydrazones were tested for their scavenging effect on the DPPH radical according to a known procedure [10] Results were expressed as milligrams of Trolox equivalents (TE) per gram of dry weight (mg TE/g d.w.) of sample calculated according to the standard calibration curve.

\section{ABTS assay}

The ABTS assay was performed by a modified previously described procedure [11]. The results were expressed as Trolox equivalents per $g$ of dry weight of sample (TEAC/g dw).

\section{FRAP assay}

To evaluate the reducing power of tested compounds, the ferric ion reducing antioxidant power (FRAP) assay [9] was undertaken with some modifications. Mean values of reducing power were expressed as milligrams equivalents ascorbic acid (AA) per gram of dry weight ( $\mathrm{mg}$ eq $\mathrm{AA} / \mathrm{g} \mathrm{dw}$ ) of sample calculated according to the standard calibration curve.

\section{RESULTS AND DISCUSSION}

Investigations on antioxidant activity of natural or synthetic molecules represent an assessment of their ability to neutralize free radical species which have harmful effects on different mammalian tissues.

Antioxidant potential of tested compounds presented in the Table 1 was determined using three in vitro assays: DPPH, ABTS and FRAP. The obtained results are presented in the Figures 1, 2 and 3 and Table 2.

Table 2. Results of three assays used

Tabela 2. Rezultati tri upotrebljena testa

\begin{tabular}{|c|c|c|c|}
\hline Compound & DPPH & ABTS & FRAP \\
\hline 1 & 146,31 & 135,67 & 658,82 \\
\hline 2 & 141,87 & 135,16 & 609,72 \\
\hline 3 & 108,40 & 134,91 & 556,41 \\
\hline 4 & 131,39 & 135,04 & 611,65 \\
\hline 5 & 135,42 & 135,67 & 645,75 \\
\hline 6 & 141,47 & 134,28 & 615,06 \\
\hline 7 & 136,23 & 135,41 & 636,48 \\
\hline 8 & 110,42 & 135,55 & 663,99 \\
\hline
\end{tabular}

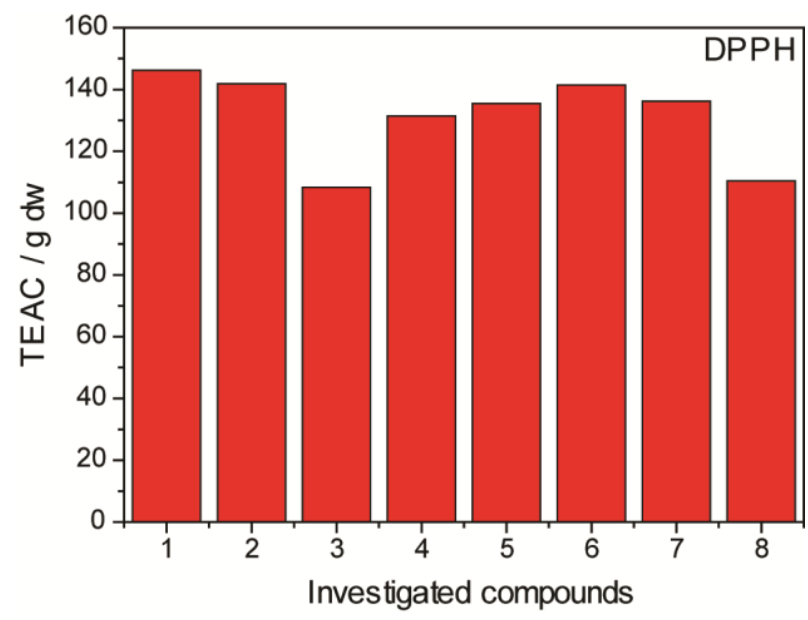

Figure 1. Assessment of antioxidant potential of tested compounds using DPPH assay

Slika 1. Procena antioksidantnog potencijala ispitivanih jedinjenja pomoću DPPH testa

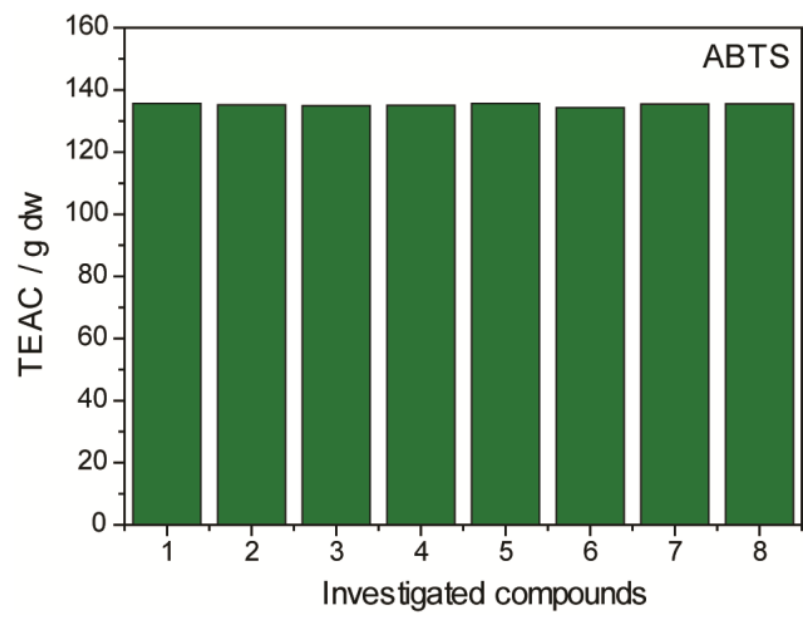

Figure 2. Assessment of antioxidant potential of tested compounds using ABTS assay

Slika 2. Procena antioksidantnog potencijala ispitivanih jedinjenja pomoću ABTS testa 


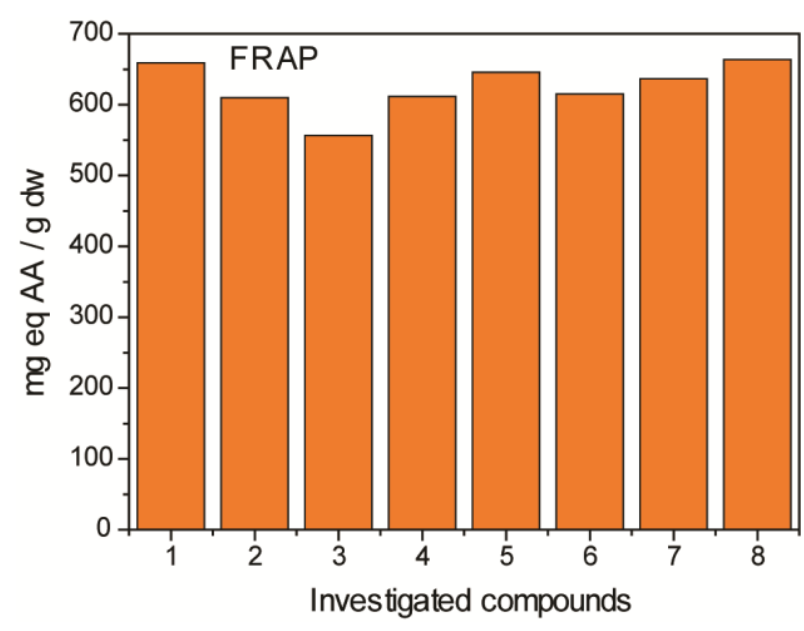

Figure 3. Assessment of antioxidant potential of tested compounds using FRAP assay

\section{Slika 3. Procena antioksidantnog potencijala ispitivanih jedinjenja pomoću FRAP testa}

There is an evidence that all tested compounds have shown a great antioxidant potential. Although the obtained values do not differ significantly, some of them are prominent. The results indicate that the highest antioxidant potential in DPPH assay shows compound 1 (146,31 TEAC/g dw), while in FRAP it is compound $8(663,99 \mathrm{mg}$ eq $A A / g ~ d w)$. On the other hand, using ABTS assay, the most active compound cannot be clearly distinguished due to extremely close values.

These results could be explained by the fact that not all assays are equally sensitive to the same compounds. Furthermore, there are no reports on any biological activity of monocarbohydrazones and therefore, it is very inconvenient to analyze the obtained results $[12,13]$. Knowing that hydroxyl groups of the benzene rings are good hydrogen donors, which can react with free radical species neutralizing them [14] it could be predicted that compound 2 will exhibit the best antioxidant capacity. However, this was not case in this study.

We can assume that the reason for such a good antioxidant activity of tested compounds lies in their structure and it depends on the position and nature of the substituent, respectively. This assumption opens various possibilities for many further researches regarding investigation of the underlying structure-activity relationship of these new synthetized compounds.

In the future analysis, an appropriate model should be chosen to explain relative scavenging activity and antioxidant potential of tested monocarbohydrazones, such as quantum chemical density functional theory and others. A more detailed analysis of the antioxidant activity would be the basis for the future biological testing.

\section{CONCLUSIONS}

In this study eight newly synthesized monocarbohydrazones were subjected to tree different antioxidant assays: DPPH, ABTS and FRAP assay, in order to evaluate their antioxidant potential. Results obtained showed that all of the tested compounds have major antioxidant power.

The highest antioxidant potential in DPPH assay was shown by compound 1 and in FRAP assay by compound 8 . On the other hand, ABTS assay shows very close values of antioxidant potential for all compounds and it is not possible to separate the most active compound. These results could be explained by the fact that not all assays are equally sensitive to the same compounds. It can be concluded that antioxidant potential depends on the structure of the compound, position and the nature of substituent present.

Obtained results of tree used assays for monocarbohydrazones are predicting great biological activity. In further studies, more biological testing will be done.

\section{Acknowledgments}

The authors acknowledge financial support of the Ministry of Education, Science and Technological Development of the Republic of Serbia (Grant No. 451-03-68/2020-14/ 200125)

\section{REFERENCES}

[1] A.Božić, A.Marinković, S.Bjelogrlić, T.R.Todorović, I.N.Cvijetić, I.Novaković, C.D.Muller, N.R.Filipović (2016) Quinoline based mono- and bis(thio)carbohydrazones: Synthesis, anticancer activity in $2 \mathrm{D}$ and $3 \mathrm{D}$ cancer and cancer stem cell models, RSC Advances, 6(106), 104763-104780.

[2] A.Fetoh, O.A.El-Gammal, G.M.Abu El-Reash (2018) Antioxidant and antitumor activities of $\mathrm{Cr}(\mathrm{III}), \mathrm{Mn}(\mathrm{II})$, $\mathrm{Fe}(\mathrm{III}), \mathrm{Cd}(\mathrm{II}), \mathrm{Zn}(\mathrm{II})$ and $\mathrm{Hg}(\mathrm{II})$ complexes containing a carbohydrazone ligand ending by 4pyridyl ring, Journal of Molecular Structure, 1173, 100-110.

[3] G.Kiran, M.Sarangapani, T.Gouthami, A.R. Narsimha (2013) Synthesis, characterization, and antimicrobial and antioxidant activities of novel bisisatin carbohydrazone derivatives, Toxicological and Environmental Chemistry, 95(3), 367-378.

[4] A.R.Božic, N.R.Filipovic, I.T.Novakovic, S.K. Bjelogrlic, J.B.Nikolic, S.Ž.Drmanic, A.D.Marinkovic (2017) Synthesis, antioxidant and antimicrobial activity of carbohydrazones, Journal of the Serbian Chemical Society, 82(5), 495-508.

[5] S.Eswaran, A.V.Adhikari, N.K.Pal, I.H.Chowdhury (2010) Design and synthesis of some new quinoline-3-carbohydrazone derivatives as potential antimycobacterial agents, Bioorganic and Medicinal 
Chemistry Letters, 20(3), 1040-1044.

[6] Y.Harinath, D.Harikishore Kumar Reddy, B.Naresh Kumar, C.Apparao, K.Seshaiah (2013) Synthesis, spectral characterization and antioxidant activity studies of a bidentate Schiff base, 5-methyl thiophene-2-carboxaldehyde-carbohydrazone and its $\mathrm{Cd}(\mathrm{II}), \mathrm{Cu}(\mathrm{II}), \mathrm{Ni}(\mathrm{II})$ and $\mathrm{Zn}(\mathrm{II})$ complexes, Spectrochimica Acta - Part A: Molecular and Biomolecular Spectroscopy, 101, 264-272.

[7] T.C.Shekhar, G.Anju (2014) Antioxidant activity by DPPH radical scavenging method of Ageratum conyzoides Linn. Leaves, American Journal of Ethnomedicine, 1(4), 244-249.

[8] R.Re, N.Pellegrini, A.Proteggente, A.Pannala, M.Yang, C.Rice-Evans (1999) Antioxidant activity applying an improved ABTS radical cation decolorization assay, Free Radical Biology and Medicine, 26(9-10), 1231-1237.

[9] I.F.F.Benzie, J.J.Strain (1996) The ferric reducing ability of plasma (FRAP) as a measure of 'antioxidant power': The FRAP assay, Analytical Biochemistry, 239(1), 70-76.
[10] S.Vlaisavljević, F.Šibul, I.Sinka, I.Zupko, I.Ocsovszki, S.Jovanović-Šanta (2018) Chemical composition, antioxidant and anticancer activity of licorice from Fruska Gora locality, Industrial Crops and Products, 112, 217-224.

[11] M.B.Arnao, A.Cano, M. Acosta (2001) The hydrophilic and lipophilic contribution to total antioxidant activity, Food Chemistry, 73(2), 239244.

[12] A.Floegel, D.-O.Kim, S.-J.Chung, S.I.Koo, O.K. Chun (2011) Comparison of ABTS/DPPH assays to measure antioxidant capacity in popular antioxidant-rich US foods, Journal of Food Composition and Analysis, 24(7), 1043-1048.

[13] E.A.Shalaby, S.M.M.Shanab (2013) Comparison of DPPH and ABTS assays for determining antioxidant potential of water and methanol extracts of Spirulina platensis, Indian Journal of Marine Sciences, 42(5), 556-564.

[14] D.M.Pereira, P.Valentão, J.A.Pereira, P.B.Andrade (2009) Phenolics: From chemistry to biology, Molecules, 14(6), 2202-2211.

\title{
IZVOD
}

\section{PROUČAVANJE ANTIOKSIDATIVNE AKTIVNOSTI ODABRANIH DERIVATA MONOKARBOHIDRAZONA}

\begin{abstract}
Mnogi derivati karbohidrazona pokazali su širok spektar bioloških aktivnosti. U prethodnim studijama ova jedinjenja su se pokazala kao odlični antikancerogeni, antitumorski, antibakterijski, antimikrobni i antioksidantni agensi. Monokarbohidrazoni, kao jedni od derivata karbohidrazona, su do sada malo istraženi. Iz tog razloga, u ovoj studiji, osam novosintetisanih monokarbohidrazona podvrgnuto je ispitivanju njihove antioksidativne aktivnosti primenom različitih testova. Da bi se utvrdila efikasnost monokarbohidrazona kao potencijalnih agenasa za uklanjanje radikala, korišćeni su DPPH, ABTS i FRAP testovi. Dobijeni rezultati predstavljaju osnovu za dalja ispitivanja ovih jedinjenja kao biološki aktivnih supstanci.
\end{abstract}

KIjučne reči: antioksidant, ABTS, biološka aktivnost, DPPH, FRAP, monokarbohidrazoni

\author{
Naučni rad \\ Rad primljen: 25.05.2020. \\ Rad korigovan: 20.06.2020. \\ Rad prihvaćen: 20.07.2020. \\ Rad je dostupan na sajtu: www.idk.org.rs/casopis
}

(C) 2021 Authors. Published by Engineering Society for Corrosion. This article is an open access article distributed under the terms and conditions of the Creative Commons Attribution 4.0 International license (https://creativecommons.org/licenses/by/4.0/) 